\title{
SYNTHESIS AND X-RAY CRYSTAL STRUCTURE OF CHIRAL DIMETHYLGALLIUM ALKOXIDES CONTAINING DIASTEREOISOMERICALLY PURE N,N-DIMETHYLAMINO ALCOHOLS
}

\author{
Herbert Schumann*, Sonja Wernik, Frank Girgsdies, and Roman Weimann \\ Institut für Anorganische und Analytische Chemie, Technische Universität Berlin, \\ Straße des 17. Juni 135, D-10623 Berlin, Germany
}

\begin{abstract}
The reaction of trimethylgallium, $\mathrm{GaMe}_{3}$, with optically active amino alcohols $(-)-(\mathrm{IR}, 2 \mathrm{~S})-2-$ dimethylamino-1-phenylpropanol and (+)-(2S,3R)-4-dimethylamino-3-methyl-1,2-diphenyl-2-butanol provides the dimeric dimethylgallium alkoxide $\left[\left(\mathrm{CH}_{3}\right)_{2} \mathrm{GaOCH}\left(\mathrm{C}_{6} \mathrm{H}_{5}\right) \mathrm{CH}\left(\mathrm{CH}_{3}\right) \mathrm{N}\left(\mathrm{CH}_{3}\right)_{2}\right]_{2}$ (1) and the monomeric compound $\left(\mathrm{CH}_{3}\right)_{2} \mathrm{GaOCC}_{6} \mathrm{H}_{5}\left(\mathrm{CH}_{2} \mathrm{C}_{6} \mathrm{H}_{5}\right) \mathrm{CH}\left(\mathrm{CH}_{3}\right) \mathrm{CH}_{2} \mathrm{~N}\left(\mathrm{CH}_{3}\right)_{2}$ (2) via a methane elimination reaction. ${ }^{1} \mathrm{H},{ }^{13} \mathrm{C}$ NMR, mass spectra as well as $\mathrm{X}$-ray crystal structure analyses of these new compounds are reported and discussed. The X-ray crystal structures confirm that the absolute configurations of the asymmetric centers in the $\mathrm{O}, \mathrm{N}$ chelating bidental ligands are retained upon formation of the corresponding coordinatively saturated complexes. Differences concerning chemical shifts of the methyl groups bound to $\mathrm{Ga}$ observed in the ${ }^{1} \mathrm{H}$ NMR spectra are explained by dynamic dissociation processes of the $\mathrm{Ga}-\mathrm{N}$ bond in the four- and five-coordinated gallium compounds.
\end{abstract}

\section{Introduction}

Organometallic compounds of group 13 have been found attractive reagents in a wide range of organic processes such as alkylation of aldehydes [1], saturated [2] and unsaturated ketones [3] and oxiranes [4]. Although dialkylaluminium compounds such as the alkoxides $\left(\mathrm{CH}_{3}\right)_{2} \mathrm{AlO}\left(\mathrm{CH}_{2}\right)_{2} \mathrm{~N}_{(}\left(\mathrm{CH}_{3}\right)_{2}$ and $\left(\mathrm{CH}_{3}\right)_{2} \mathrm{AlOCH}_{2} \mathrm{C}\left(\mathrm{CH}_{3}\right)_{2} \mathrm{OCH}_{3}$ proved to be efficient alkylation reagents [5], the real potential of organometallic compounds in organic synthesis has not yet been exhausted. During the past several years, the application of organometallic complexes in regio- and stereospecific organic synthesis [6] has led to a great interest in preparation and characterization of these chiral metal reagents. As part of our interest in intramolecularly base-stabilized, nonracemic chiral organogallium compounds, two dialkylgallium complexes have been prepared by reaction of trimethylgallium with optically active amino alcohols in a 1:1 stoichiometry. In this paper we report on the synthesis, spectroscopic investigations and structural characterization of the new compounds.

\section{Materials and Methods}

General procedures:

All reactions were carried out in an atmosphere of dry, oxygen-free argon. CHN analyses were performed on a Perkin Elmer $240 \mathrm{C}$ elemental analyzer. Mass spectra (electron impact ionization) were obtained on the instrument Varian MAT $311 \mathrm{~A}(70 \mathrm{eV})$. NMR spectra were recorded on the spectrometer Bruker ARX $200\left({ }^{\mathrm{l}} \mathrm{H}\right.$ NMR at $200 \mathrm{MHz}$ in $\mathrm{C}_{6} \mathrm{D}_{6} ;{ }^{13} \mathrm{C}\left\{{ }^{1} \mathrm{H}\right\} \mathrm{NMR}$ in $\left.\mathrm{C}_{6} \mathrm{D}_{6}\right)$; chemical shifts are referenced to $\left(\mathrm{CH}_{3}\right)_{4} \mathrm{Si}$ with positive shifts referring to lower field.

Preparation of $\left[\left(\mathrm{CH}_{3}\right)_{2} \mathrm{GaOCH}\left(\mathrm{C}_{6} \mathrm{H}_{5}\right) \mathrm{CH}\left(\mathrm{CH}_{3}\right) \mathrm{N}\left(\mathrm{CH}_{3}\right)_{2}\right]_{2}(\mathbf{1})$ :

$3.03 \mathrm{~g}(26.4 \mathrm{mmol})$ of $\mathrm{Ga}(\mathrm{CH})_{3}$ were dissolved in $30 \mathrm{ml}$ of diethyl ether and an etheral solution $(80 \mathrm{ml})$ of $4.73 \mathrm{~g}$ (26.4 mmol) of (-)-(1R,2S)-2-dimethylamino-1-phenylpropanol was added dropwise with stirring. After further stirring for $12 \mathrm{~h}$, the solvent was distilled off. The resulting residue was purified by fractionated crystallization from diethyl ether at room temperature. Colorless crystals were obtained. Yield: $5.9 \mathrm{~g} \mathrm{(80 \% ).} \mathrm{M.p.}$ (sealed) $110^{\circ} \mathrm{C}$. Anal. Found: $\mathrm{C}, 52.87 ; \mathrm{H}, 8.04 ; \mathrm{N}, 5.17 . \mathrm{C}_{13} \mathrm{H}_{22} \mathrm{GaNO}$ calcd: $\mathrm{C}, 56.16 ; \mathrm{H}, 7.98 ; \mathrm{N}, 5.04$. ${ }^{1} \mathrm{H}$ NMR $(\delta, \mathrm{ppm}):-0.12\left(\mathrm{~s}, 6 \mathrm{H}, \mathrm{GaCH}_{3}\right), 0.62\left(\mathrm{~d},{ }^{3} \mathrm{~J}=6.9 \mathrm{~Hz}, 3 \mathrm{H}, \mathrm{CH}_{3}\right), 1.71\left(\mathrm{~s}, 6 \mathrm{H}, \mathrm{NCH}_{3}\right), 2.45(\mathrm{~m}, 1 \mathrm{H}, \mathrm{NCH}), 5.11\left(\mathrm{~d},{ }^{3} \mathrm{~J}\right.$ $=4.6 \mathrm{~Hz}, 1 \mathrm{H}, \mathrm{CHPh}), 7.08-7.58(\mathrm{~m}, 5 \mathrm{H}$, aromatic $\mathrm{H}) .{ }^{13} \mathrm{C}\left\{{ }^{l} \mathrm{H}\right\} \mathrm{NMR}(\delta, \mathrm{ppm}):-5.68\left(\mathrm{GaCH}_{3}\right), 9.39\left(\mathrm{CH}_{3}\right), 43.46$ $\left(\mathrm{NCH}_{3}\right), 67.67(\mathrm{NCH}), 75.18(\mathrm{CHPh}), 126.38,126.74,128.30,144.66$ (aromatic C). MS (EI, $120^{\circ} \mathrm{C}, 70 \mathrm{eV}, \mathrm{m} / \mathrm{z}$ (\%)): 262/264 (43.7) $\left[\mathrm{M}-\mathrm{CH}_{3}\right]^{+}, 99 / 101(18.7)\left[\mathrm{Ga}\left(\mathrm{CH}_{3}\right)_{2}\right]^{+}, 72(100)\left[\mathrm{C}_{4} \mathrm{H}_{30} \mathrm{~N}\right]^{+}$. 
Preparation of $\left(\mathrm{CH}_{3}\right)_{2} \mathrm{GaOCC}_{6} \mathrm{H}_{5}\left(\mathrm{CH}_{2} \mathrm{C}_{6} \mathrm{H}_{5}\right) \mathrm{CH}\left(\mathrm{CH}_{3}\right) \mathrm{CH}_{2} \mathrm{~N}\left(\mathrm{CH}_{3}\right)_{2}$ (2):

$3.55 \mathrm{~g}(30.9 \mathrm{mmol})$ of $\mathrm{Ga}\left(\mathrm{CH}_{3}\right)_{3}$ were dissolved in $25 \mathrm{ml}$ of pentane and a solution of $8.76 \mathrm{~g}(30.9 \mathrm{mmol})$ of (+)-(2S,3R)-4-dimethylamino-3-methyl-1,2-diphenyl-2-butanol in $65 \mathrm{ml}$ of pentane was added dropwise with stirring. After the addition was complete $(1.5 \mathrm{~h})$, the resulting cloudy mixture was stirred for further $12 \mathrm{~h}$. The solvent was distilled off to yield a residue, which was washed with pentane (3x) leaving behind a white solid. An etheral solution of $3.0 \mathrm{~g}$ of the desired compound was cooled to $-30^{\circ} \mathrm{C}$, affording transparent crystals. Yield: $8.0 \mathrm{~g}$ (68\%). M.p. (sealed) $150^{\circ} \mathrm{C}$. Anal. Found: $\mathrm{C}, 65.42 ; \mathrm{H}, 7.96 ; \mathrm{N}, 4.37$. $\mathrm{C}_{21} \mathrm{H}_{30} \mathrm{GaNO}$ calcd: $\mathrm{C}, 66.00 ; \mathrm{H}, 7.91 ; \mathrm{N}$, $3.66 \%$. ${ }^{1} \mathrm{H}$ NMR $(\delta, \mathrm{ppm}):-0.27\left(\mathrm{~s}, 3 \mathrm{H}, \mathrm{GaCH}_{3}\right),-0.11\left(\mathrm{~s}, 3 \mathrm{H}, \mathrm{GaCH}_{3}\right), 0.74\left(\mathrm{~d},{ }^{3} \mathrm{~J}=7.4 \mathrm{~Hz}, 3 \mathrm{H}, \mathrm{CH}_{3}\right), 0.97(\mathrm{~m}$, $1 \mathrm{H}, \mathrm{CH}), 1.45\left(\mathrm{~s}, 3 \mathrm{H}, \mathrm{NCH}_{3}\right), 1.56\left(\mathrm{~s}, 3 \mathrm{H}, \mathrm{NCH}_{3}\right), 1.94\left(\mathrm{~m}, 1 \mathrm{H}, \mathrm{NCH}_{2}\right), 2.48\left(\mathrm{dd},{ }^{2} \mathrm{~J}=12.8 \mathrm{~Hz},{ }^{3} \mathrm{~J}=9.3 \mathrm{~Hz}, 1 \mathrm{H}\right.$, $\mathrm{NCH}_{2}$ ), 3.22 (d, $\left.{ }^{2} \mathrm{~J}=13.4 \mathrm{~Hz}, 1 \mathrm{H}, \mathrm{CH}_{2} \mathrm{Ph}\right), 3.42\left(\mathrm{~d},{ }^{2} \mathrm{~J}=13.4 \mathrm{~Hz}, 1 \mathrm{H}, \mathrm{CH}_{2} \mathrm{Ph}\right), 7.00-7.76(\mathrm{~m}, 10 \mathrm{H}$, aromatic $\mathrm{H})$. ${ }^{13} \mathrm{C}\left\{{ }^{1} \mathrm{H}\right\}$ NMR ( $\left.8, \mathrm{ppm}\right):-7.22\left(\mathrm{GaCH}_{3}\right),-4.71\left(\mathrm{GaCH}_{3}\right), 18.86\left(\mathrm{CH}_{3}\right), 40.43(\mathrm{CH}), 45.36\left(\mathrm{NCH}_{3}\right), 48.48\left(\mathrm{CH}_{2} \mathrm{~N}\right)$, $48.52\left(\mathrm{NCH}_{3}\right), 64.60\left(\mathrm{CH}_{2} \mathrm{Ph}\right), 80.30\left(\mathrm{C}_{q}\right), 125.78,126.09,127.15,127.63,128.89,131.62,139.75,146.88$ (aromatic C). MS (EI, $120^{\circ} \mathrm{C}, 70 \mathrm{eV}, \mathrm{m} / \mathrm{z}(\%)$ ): 366/368 (6.5) $\left[\mathrm{M}-\mathrm{CH}_{3}\right]^{+}, 290 / 292(34.6)\left[\mathrm{M}-\mathrm{C}_{7} \mathrm{H}_{7}\right]^{+}, 99 / 101$ (7.3) $\left[\mathrm{Ga}\left(\mathrm{CH}_{3}\right)_{2}\right]^{+}, 91(2.7)\left[\mathrm{C}_{7} \mathrm{H}_{7}\right]^{+}, 77(2.0)\left[\mathrm{C}_{6} \mathrm{H}_{5}\right]^{+}, 58(100)\left[\mathrm{C}_{3} \mathrm{H}_{8} \mathrm{~N}\right]^{+}$.

\begin{tabular}{|c|c|c|}
\hline \multicolumn{3}{|c|}{ Table L.: Crystallographic data for 1 and 2} \\
\hline $\begin{array}{l}\text { compound } \\
\text { empirical formula } \\
\mathrm{f}_{\mathrm{w}}, \mathrm{g} / \mathrm{mol}\end{array}$ & $\begin{array}{l}1 \\
{\left[\mathrm{C}_{13} \mathrm{H}_{22} \mathrm{GaNO}_{2}\right.} \\
556.08\end{array}$ & $\begin{array}{l}2 \\
\mathrm{C}_{21} \mathrm{H}_{30} \mathrm{GaNO} \\
382.18\end{array}$ \\
\hline cryst dim., mm & $0.24 \times 0.33 \times 0.39$ & $0.18 \times 0.23 \times 0.27$ \\
\hline temperature, $\mathrm{K}$ & $163(2)$ & $187(2)$ \\
\hline crystal system & tetragonal & orthorhombic \\
\hline space group & $\mathrm{P}_{4} 2_{1} 2$ & $P 2_{1} 2_{1} 2_{1}$ \\
\hline a, $\AA$ & $9.113(2)$ & $13.360(3)$ \\
\hline b, $\AA$ & $9.113(2)$ & $9.2343(13)$ \\
\hline c, $\AA$ & $34.409(9)$ & $16.412(4)$ \\
\hline $\mathrm{V}, \AA^{3}$ & 2857.3(11) & $2024.7(7)$ \\
\hline $\mathrm{z}$ & 4 & 4 \\
\hline$P_{\text {calc }} ; \mathrm{g} \mathrm{cm}^{-3}$ & 1.293 & 1.254 \\
\hline$\mu, \mathrm{cm}^{-1}$ & 1.908 & 1.395 \\
\hline $\mathrm{F}(000)$ & 1168 & \\
\hline radiation & \multicolumn{2}{|c|}{$\mathrm{Mo} \mathrm{K}_{\alpha}, \lambda=0.71069$} \\
\hline $2 \theta$ range, deg & $4-55$ & $2-55$ \\
\hline index ranges & $0 \leq \mathrm{h}<11,0<\mathrm{k}<11,0 \leq 1<44$ & $-17<\mathrm{h}<17,0<\mathrm{k}<10,0<1<21$ \\
\hline scan type & $\omega-2 \theta$ & $\omega-2 \theta$ \\
\hline reflections collected & 3681 & 4428 \\
\hline independent reflections & $3251[\mathrm{R}(\mathrm{int})=0.1163]$ & $4101[\mathrm{R}$ (int) $=0.0366]$ \\
\hline absorption correction & none & $\begin{array}{l}\text { DIFABS [8] } \\
\text { (min.: } 0.877, \max .: 1.144)\end{array}$ \\
\hline observed reflections & 3245 & 4081 \\
\hline number of variables & 150 & 217 \\
\hline $\mathrm{GOF}^{*}$ & 1.054 & 1.012 \\
\hline final $R$ indices $* *(I>2 \sigma(I))$ & $\mathrm{R}_{1}=0.0421, \mathrm{R}_{\mathrm{w} 2}=0.0805$ & $R_{1}=0.0428, R_{w 2}=0.0912$ \\
\hline absolute structure parameter & $-0.03(2)$ & $0.01(2)$ \\
\hline largest diff. peak and hole, e/ $\AA^{3}$ & 0.322 and -0.347 & 0.303 and -0.404 \\
\hline \multicolumn{3}{|c|}{$\begin{array}{l}* \mathrm{GOF}=\left[\Sigma \mathrm{w}\left(\left|\mathrm{F}_{\mathrm{o}}\right|-\left|\mathrm{F}_{\mathrm{c}}\right|\right)^{2} /\left(\mathrm{N}_{\mathrm{obs}}-\mathrm{N}_{\mathrm{param}}\right)\right]^{1 / 2} \\
\left.=\Sigma\left(\left|\mathrm{F}_{\mathrm{o}}\right|-\left|\mathrm{F}_{\mathrm{c}}\right|\right) / \Sigma\left|\mathrm{F}_{\mathrm{o}}\right|\right), \mathrm{R}_{\mathrm{w2} 2}=\left[\Sigma \mathrm{w}\left(\left|\mathrm{F}_{\mathrm{o}}\right|-\left|\mathrm{F}_{\mathrm{c}}\right|\right)^{2} / \Sigma \mathrm{w}\left|\mathrm{F}_{\mathrm{o}}\right|^{2}\right]^{1 / 2}, \\
\mathrm{w}=\mathrm{q} /\left[\left(\sigma \mathrm{F}_{\mathrm{o}}\right)^{2}+(\alpha \mathrm{P})^{2}+\mathrm{bP}+\mathrm{d}+\mathrm{e} \sin \theta\right] .\end{array}$} \\
\hline
\end{tabular}


$\mathrm{X}$-ray Structure Analysis of 1 and 2:

The details of the crystal data with a summary of intensity data collection parameters and structural refinement for 1 and 2 are presented in table I. Atomic coordinates and equivalent isotropic displacement parameters for 1 and 2 are listed in table II. Data collection was carried out with an Enraf-Nonius CAD-4 automatic diffractometer, controlled by a PC and fitted with a low-temperature equipment. The cell parameters were obtained from a least squares treatment of the SET4 setting angles of 25 reflections in the range of $14.5^{\circ}<2 \theta<24.3^{\circ}(1)$ and $16.7^{\circ}<2 \theta<22.5^{\circ}(2)$. Both raw data sets were corrected for Lorentz and polarisation effects [7] and 1 for absorption effects [8]. The structures were solved with direct methods (SHELXS 86 [9]) and refined by full-matrix least squares using SHELXL 93 [10], which minimizes $R_{w 2}$ (based on $\mathrm{F}^{2}$ ). All non-hydrogen atoms were refined anisotropically. Hydrogen atoms were calculated in idealized positions $\left(C-H 0.96 \AA, U_{\mathrm{so}}=0.08 \AA^{2}\right)$. Scattering factors were taken from the ref. [11-13]. All calculations were performed on a IBM Risk 6000 computer. The ORTEP [14] program was used to obtain the drawings. Further details of the crystal structure investigation are available on request from the Fachinformationszentrum Karlsruhe GmbH, D-76344 Eggenstein-Leopoldshafen (FRG), on quoting the depository numbers CSD-404593 (1) and CSD-404594 (2), respectively.

Table II.: Atomic coordinates $\left(\times 10^{4}\right)$ and equivalent isotropic displacement parameters $\left(\AA^{2} \times 10^{3}\right)$ for 1 and 2 with estimated standard deviations.

\begin{tabular}{|c|c|c|c|c|c|c|c|c|c|}
\hline \multirow{3}{*}{$\begin{array}{l}\text { Atom } \\
\mathrm{Ga}\end{array}$} & \multicolumn{3}{|c|}{ Compound 1} & \multirow{3}{*}{$\begin{array}{l}\mathbf{U}_{\text {eq }}{ }^{*} \\
25(1)\end{array}$} & \multicolumn{5}{|c|}{ Compound 2} \\
\hline & $\mathbf{z} / \mathbf{a}$ & $y / b$ & $\mathbf{z} / \mathbf{c}$ & & Atom & $\mathbf{z} / \mathbf{a}$ & $y / b$ & $z / c$ & $\mathbf{U}_{\text {eq }}{ }^{*}$ \\
\hline & $7914(1)$ & $5483(1)$ & $5065(1)$ & & $\mathrm{Ga}$ & $1421(1)$ & $1744(1)$ & $1659(1)$ & $25(1)$ \\
\hline$C(1)$ & $7676(6)$ & $3606(5)$ & $5345(2)$ & $43(1)$ & $C(1)$ & $226(3)$ & $682(5)$ & 2049(3) & $42(1)$ \\
\hline$C(2)$ & $9465(5)$ & $6901(5)$ & $5202(1)$ & $36(1)$ & $C(2)$ & $2202(3)$ & $2975(5)$ & $2408(2)$ & $38(1)$ \\
\hline $\mathrm{O}$ & $6602(3)$ & $6129(3)$ & $4667(1)$ & $24(1)$ & $\mathrm{O}$ & $1077(2)$ & $2607(3)$ & $684(2)$ & $22(1)$ \\
\hline$C(3)$ & 6735(4) & $5786(4)$ & $4276(1)$ & $27(1)$ & $C(3)$ & $1703(2)$ & $3004(4)$ & $39(2)$ & $20(1)$ \\
\hline$C(31)$ & $5609(5)$ & $4615(5)$ & $4154(1)$ & $29(1)$ & $C(4)$ & $1141(3)$ & $2699(4)$ & $-756(2)$ & $21(1)$ \\
\hline$C(32)$ & $4957(5)$ & $3699(5)$ & $4425(1)$ & $34(1)$ & $C(5)$ & $1390(3)$ & $3348(4)$ & $-1505(2)$ & $28(1)$ \\
\hline$C(33)$ & $3920(5)$ & $2657(6)$ & $4312(2)$ & $48(1)$ & $C(6)$ & $902(3)$ & $2978(4)$ & $-2211(2)$ & $33(1)$ \\
\hline$C(34)$ & $3499(5)$ & $2567(6)$ & $3930(2)$ & $56(2)$ & $C(7)$ & $148(3)$ & $1951(5)$ & $-2200(2)$ & $36(1)$ \\
\hline$C(35)$ & $4103(6)$ & $3476(6)$ & $3660(2)$ & $53(2)$ & $C(8)$ & $-127(3)$ & $1324(4)$ & $-1472(2)$ & $32(1)$ \\
\hline$C(36)$ & $5155(5)$ & $4496(5)$ & $3770(2)$ & $42(1)$ & $C(9)$ & $366(3)$ & $1700(4)$ & $-757(2)$ & $25(1)$ \\
\hline$C(4)$ & $8361(4)$ & $5456(5)$ & $4188(1)$ & $32(1)$ & $C(10)$ & $1985(3)$ & $4634(4)$ & $131(2)$ & $26(1)$ \\
\hline$C(41)$ & $8668(6)$ & $4944(5)$ & $3772(1)$ & $46(1)$ & $C(11)$ & $1137(3)$ & $5699(4)$ & $85(2)$ & $25(1)$ \\
\hline $\mathrm{N}$ & 9006(4) & $4523(4)$ & $4499(1)$ & $30(1)$ & $\mathrm{C}(1$ & $1080(3)$ & $6687(5)$ & $-557(2)$ & $36(1)$ \\
\hline$C(5)$ & $8724(5)$ & $2936(5)$ & $4443(1)$ & $41(1)$ & $C(13)$ & $327(4)$ & $7720(5)$ & $-579(3)$ & $49(1)$ \\
\hline \multirow[t]{9}{*}{$C(6)$} & $10608(5)$ & $4728(6)$ & $4519(2)$ & $49(1)$ & $C(14)$ & $-370(4)$ & $7801(5)$ & $24(3)$ & $49(1)$ \\
\hline & & & & & $C(15)$ & $-342(3)$ & $6816(5)$ & $662(3)$ & $45(1)$ \\
\hline & & & & & $C(16)$ & $420(3)$ & $5772(4)$ & $688(3)$ & $32(1)$ \\
\hline & & & & & $C(17)$ & $2700(3)$ & $2108(4)$ & $72(2)$ & $26(1)$ \\
\hline & & & & & $C(18)$ & $3362(3)$ & $2203(5)$ & $-689(3)$ & $39(1)$ \\
\hline & & & & & C(19) & $2503(3)$ & $518(4)$ & $268(2)$ & $29(1)$ \\
\hline & & & & & $\mathrm{N}$ & $2407(2)$ & 201(3) & $1158(2)$ & $27(1)$ \\
\hline & & & & & $C(20)$ & $2010(3)$ & $-1297(4)$ & $1254(3)$ & $40(1)$ \\
\hline & & & & & $C(21)$ & $3414(3)$ & $253(4)$ & $1538(3)$ & $37(1)$ \\
\hline
\end{tabular}




\section{Results and Discussion}

Synthesis of diastereoisomerically pure organogallium compounds:

The new gallium complexes were prepared via methane elimination reactions from the activehydrogen containing amino alcohols (-)-(1R,2S)-2-dimethylamino-1-phenylpropanol and (+)-(2S,3R)-4dimethylamino-3-methyl-1,2-diphenyl-2-butanol with trimethylgallium:

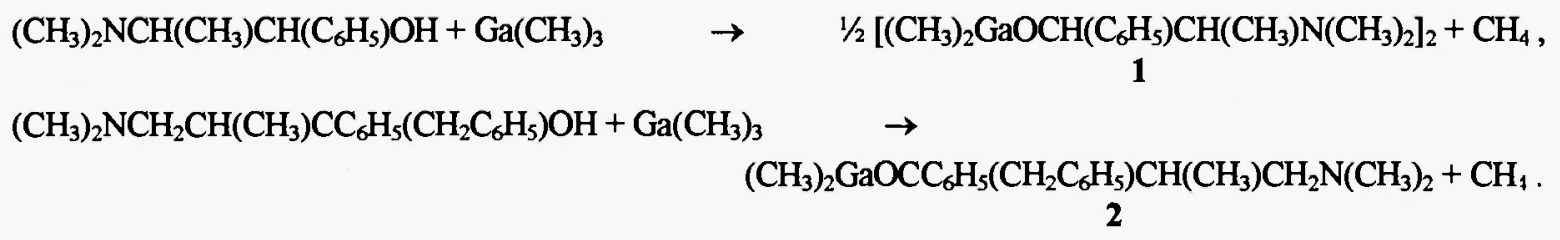

Compounds 1 and 2 have been isolated as colorless, transparent crystals. Each of the new compounds is slightly air and moisture sensitive, decomposing on exposure to air. They are well soluble in unsaturated hydrocarbons such as benzene or toluene. The strongest signals in the mass spectra of 1 and 2 were due to $\alpha$ fragmentation, the loss of $\left[\mathrm{RCH}=\mathrm{N}\left(\mathrm{CH}_{3}\right)_{2}\right]^{+}$ions. The absence of the parent ion signals is common in compounds containing the dimethyl gallium moiety [15]. The ion $\left[\mathrm{M}_{-}-\mathrm{CH}_{3}\right]^{+}$is found with low intensity for compound 2 , whereas the mass spectrum of compound 1, which was found to be dimeric in the solid state, shows no masses heavier than the monomer ion minus one methyl group $\left[\mathrm{M}-\mathrm{CH}_{3}\right]^{+}$at $\mathrm{m} / \mathrm{z} 262$ and 264 , indicating a preferred monomeric constitution in the gas phase for compound 1 . The relative intensities of the doubled mass peaks of the gallium containing ions agree well with those predicted from the isotopic distribution of the metal atom $\left[{ }^{69} \mathrm{Ga}(60)\right.$, $\left.{ }^{\pi} \mathrm{Ga}(40)\right]$.

\begin{tabular}{lccc}
\hline \multicolumn{4}{c}{ Table III.: Selected bond distances $(\AA)$ and angles $\left(^{\circ}\right)$ for 1 and 2 } \\
\hline & Compound 1 & \multicolumn{2}{c}{ Compound 2 } \\
$\mathrm{Ga}-\mathrm{C}(1)$ & $1.974(4)$ & $\mathrm{Ga}-\mathrm{C}(1)$ & $1.979(4)$ \\
$\mathrm{Ga}-\mathrm{C}(2)$ & $1.971(4)$ & $\mathrm{Ga}-\mathrm{C}(2)$ & $1.973(4)$ \\
$\mathrm{Ga}-\mathrm{O}$ & $1.91(3)$ & $\mathrm{Ga}-\mathrm{O}$ & $1.846(2)$ \\
$\mathrm{Ga}-\mathrm{N}$ & $2.357(3)$ & $\mathrm{Ga}-\mathrm{N}$ & $2.107(3)$ \\
$\mathrm{Ga}-\mathrm{O}^{\prime}$ & $2.128(3)$ & & $120.7(2)$ \\
$\mathrm{C}(1)-\mathrm{Ga}-\mathrm{C}(2)$ & $122.0(2)$ & $\mathrm{C}(1)-\mathrm{Ga}-\mathrm{C}(2)$ & $107.1(2)$ \\
$\mathrm{C}(1)-\mathrm{Ga}-\mathrm{O}$ & $123.2(2)$ & $\mathrm{C}(1)-\mathrm{Ga}-\mathrm{O}$ & $115.0(2)$ \\
$\mathrm{C}(1)-\mathrm{Ga}-\mathrm{O}^{\prime}$ & $96.9(2)$ & $\mathrm{C}(2)-\mathrm{Ga}-\mathrm{O}$ & $107.2(2)$ \\
$\mathrm{C}(1)-\mathrm{Ga}-\mathrm{N}$ & $97.3(2)$ & $\mathrm{C}(1)-\mathrm{Ga}-\mathrm{N}$ & $107.6(2)$ \\
$\mathrm{C}(2)-\mathrm{Ga}-\mathrm{O}$ & $114.7(2)$ & $\mathrm{C}(2)-\mathrm{Ga}-\mathrm{N}$ & $12.3(1)$ \\
$\mathrm{C}(2)-\mathrm{Ga}-\mathrm{O}^{\prime}$ & $97.5(2)$ & $\mathrm{O}-\mathrm{Ga}-\mathrm{N}$ & $107.6(2)$ \\
$\mathrm{C}(2)-\mathrm{Ga}-\mathrm{N}$ & $97.9(2)$ & $\mathrm{Ga}-\mathrm{O}-\mathrm{C}(3)$ & $111.3(3)$ \\
$\mathrm{O}-\mathrm{Ga}-\mathrm{O}^{\prime}$ & $71.6(1)$ & $\mathrm{Ga}-\mathrm{N}-\mathrm{C}(19)$ & $112.4(2)$ \\
$\mathrm{O}-\mathrm{Ga}-\mathrm{N}$ & $77.6(1)$ & $\mathrm{Ga}-\mathrm{N}-\mathrm{C}(20)$ & \\
$\mathrm{O}^{\prime}-\mathrm{Ga}-\mathrm{N}$ & $149.1(1)$ & $\mathrm{Ga}-\mathrm{N}-\mathrm{C}(21)$ & \\
$\mathrm{Ga}-\mathrm{O}-\mathrm{Ga}$ & $103.1(1)$ & & \\
$\mathrm{Ga}-\mathrm{O}-\mathrm{C}(3)$ & $124.9(2)$ & & \\
$\mathrm{Ga}-\mathrm{O}-\mathrm{C}(3)$ & $129.3(2)$ & & \\
$\mathrm{Ga}-\mathrm{N}-\mathrm{C}(4)$ & $102.5(2)$ & & \\
$\mathrm{Ga}-\mathrm{N}-\mathrm{C}(5)$ & $113.5(3)$ & & \\
$\mathrm{Ga}-\mathrm{N}-\mathrm{C}(6)$ & $109.5(3)$ & & \\
\hline \multicolumn{5}{c}{ Symmetry transformation (') used to generate equivalent atoms: $\mathrm{y}, \mathrm{x}, 1-\mathrm{z}$} \\
\hline
\end{tabular}


X-ray structures:

The X-ray structure of 1 shows dimeric units with a twofold rotational symmetry and gallium in a penta- coordinate environment (Table III, Figure 1). This structure pattern is known from several related compounds [16] and therefore not surprising. The crystal stucture of a closely similar compound $\left.\left(\left[\left(\mathrm{CH}_{3}\right)_{2} \mathrm{Al}\left(\mathrm{O}-(\mathrm{R})-\mathrm{CHC}_{6} \mathrm{H}_{5}-(\mathrm{S})-\mathrm{CH}(\mathrm{S})-\mathrm{NHCH}_{3}\right) \mathrm{CH}_{3}\right)\right]_{2}\right)$ was published earlier [17]. A closer look at both structures reveals that they are nearly, but not exactly isotypic, since they differ in the number of atoms $\left(-\mathrm{N}\left(\mathrm{CH}_{3}\right)_{2}\right.$ vs. $\left.-\mathrm{NHCH}_{3}\right)$. Compound 1 crystallizes in the space group $\mathrm{P}_{3} 2_{1} 2$ (No.96), while Oliver and coworkers claim the enantiomorphous space group $\mathrm{P}_{1} 2_{1} 2$ (No.92) for the structure of the aluminium derivative. This is probably a mistake, since the atomic coordinates as well as the published drawing of the molecule show $1 \mathrm{~S}, 2 \mathrm{R}$ configuration for the ligand, while the text refers to the $1 \mathrm{R}, 2 \mathrm{~S}$ compound.

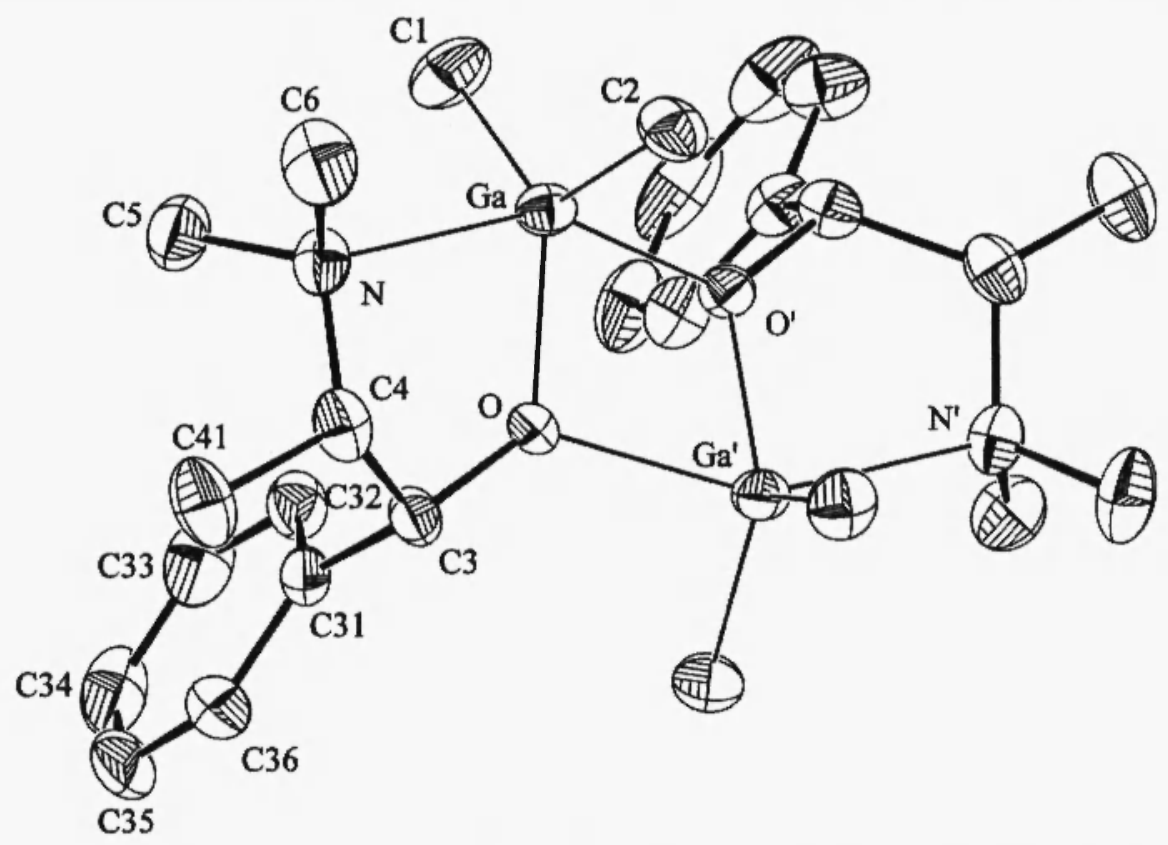

Figure 1.: Molecular structure of 1. Hydrogen atoms are omitted for clarity, and thermal ellipsoids are drawn at the $50 \%$ level.

Compound 2, in contrast, is monomeric in the solid state (Table III, Figure 2). This is remarkable, since this means that there is another factor that prevents dimerization via formation of a four-membered $\mathrm{Ga}_{2} \mathrm{O}_{2}$ ring. In the crystal structures known so far, monomeric units usually result from one of the following effects: (i) the formation of intermolecular hydrogen bonds (ligands of $-\mathrm{O}-\mathrm{R}_{-} \mathrm{NH}_{2}$ type [18]), which saturate the primary donor atom $(O)$ of the ligand, or (ii) mesomeric delocalization between the primary and secondary donor atoms [19], which reduces the negative charge of the primary donor atom and thus may decrease the tendency of dimerization. The only exception from this pattern, to our knowledge, is the aluminium analogue of 2 , published very recently [20]. The authors attribute the formation of a monomeric unit to the high stability of the six-membered chelate ring. Related dimeric structures with six-membered rings are known, however [16(k), 21]. We suspect that the presence of both a phenyl and a benzyl group in the direct neighborhood of the oxygen atom prevents the formation of dimers via this atom for steric reasons, rendering the metal atom in a tetra- coordinate environment.

Since a coordination number of four is the minimum required for a stable complex in this context, it is clear that the Ga-N coordinative bond is essential in 2, while it is just an additional stabilizing factor in 1. This can be verified by comparison of the bond lenghts ( 2.11 vs. $2.36 \AA$, respectively), which shows that the corresponding bond in 1 is much weaker than in 2 and, furthermore, the weakest of the five bonds to $\mathrm{Ga}$ in the dimer. The consequences of this situation for the coordination behavior of the molecules in solution is 
discussed in the NMR section below. The Ga-N bond distance observed for 2 is in the typical range of Ga-N dative bond lengths for tetrahedrally coordinate gallium [15(a), 18(a), 22].

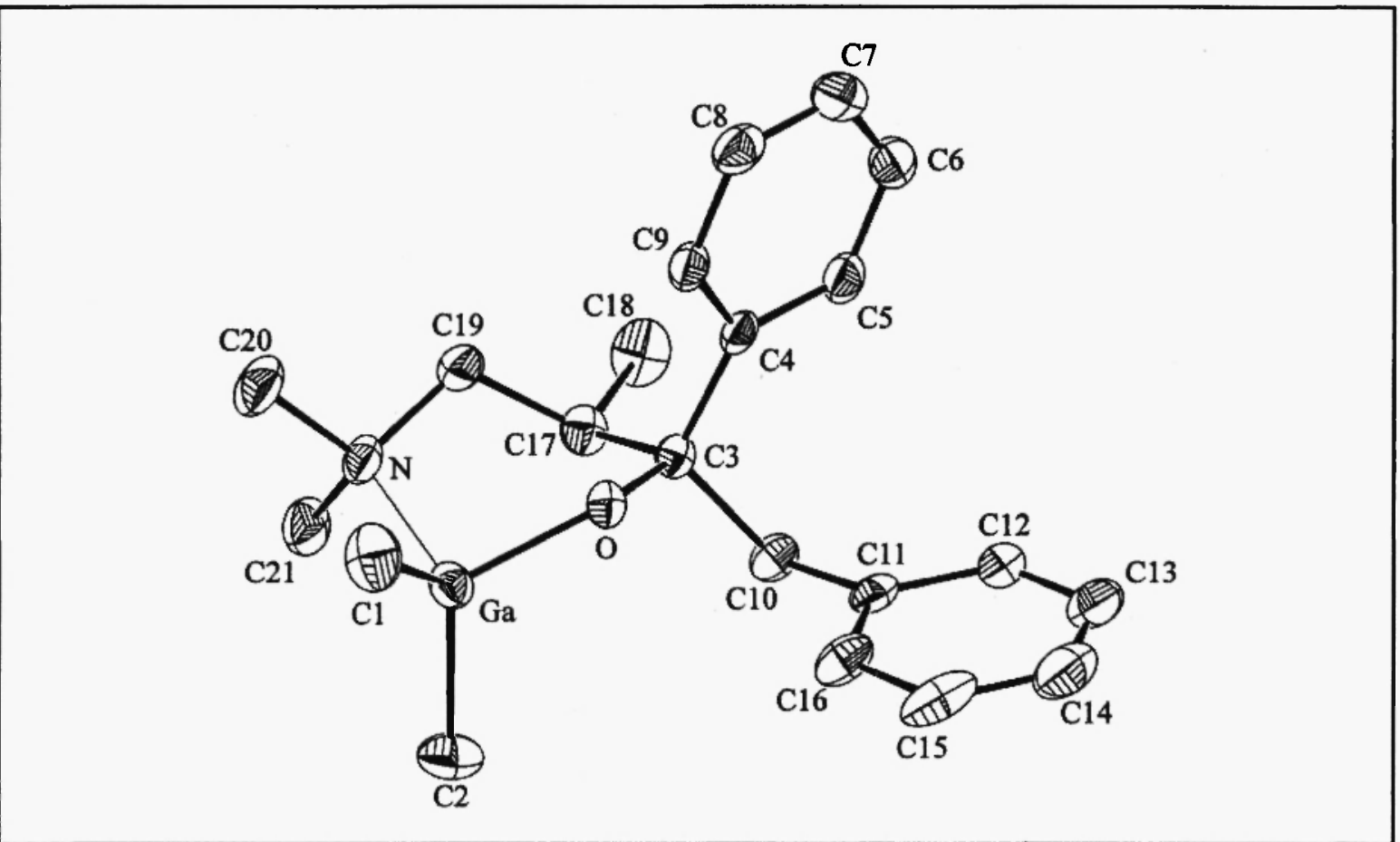

Figure 2.: Molecular structure of 2. Hydrogen atoms are omitted for clarity, and thermal ellipsoids are drawn at the $50 \%$ level.

${ }^{1} \mathrm{H}$ and ${ }^{13} \mathrm{C}$ NMR spectroscopy:

The ${ }^{1} \mathrm{H}$ and ${ }^{13} \mathrm{C}$ NMR spectra of the compounds are consistent with the reactions and structures described. The resonances at $3.47 \mathrm{ppm}$ and $8.10 \mathrm{ppm}$ for the $\mathrm{OH}$ protons of the corresponding ligands are missing in the spectra of the complexes formed, so there is no evidence of hydroxy protons of the starting amino alcohols. Only one diastereoisomer is detected for compound 1 and 2 , respectively, in the ${ }^{1} \mathrm{H}$ and ${ }^{13} \mathrm{C}$ NMR spectra, indicating diastereoisomerically pure complexes.

In the ${ }^{1} \mathrm{H}$ NMR spectrum of both, compound 1 as well as the corresponding ligand, the expected single set of resonances for all proton containing groups can be observed: The $\mathrm{CH}_{3}-$, NCH- and $\mathrm{CHPh}-$ groups of the free ligand are detected as a doublet, a quartet and a doublet, respectively, and show the same coupling pattern at similar chemical shifts when complex 1 is formed. The $\mathrm{NMe}_{2}$-group at $1.71 \mathrm{ppm}$ as well as the $\mathrm{GaMe}_{2}$-unit at $-0.12 \mathrm{ppm}$ are found as only one sharp signal, respectively. This seems to be somewhat surprising considering the different environments of the two methyl groups on both the gallium and nitrogen atom in the solid state structure. An explanation which is in line with the NMR data found, concerning the collapse of the methyl groups of both, the $\mathrm{GaMe}_{2}$ - and $\mathrm{NMe}_{2}$ - moiety, in solution, is the following: The weak Ga-N dative bond in 1 may undergo dissociation in solution, permitting transition from the five-coordinate to an intermediate four-coordinate gallium complex, which enables rapid rotation around the $\mathrm{O}-\mathrm{C}$ bond without disruption of the $\mathrm{Ga}_{2} \mathrm{O}_{2}$ ring [16]. The rapid exchange between these possible conformations gives rise to a single magnetic environment on the NMR time scale. In contrast to 1 , in the similar dimeric $\mathrm{Al}$ compound $\left[\left(\mathrm{CH}_{3}\right)_{2} \mathrm{Al}(\mathrm{O}-(\mathrm{R})-\right.$ $\left.\left.\mathrm{CHC}_{6} \mathrm{H}_{5}-(\mathrm{S})-\mathrm{CH}\left((\mathrm{S})-\mathrm{NHCH}_{3}\right) \mathrm{CH}_{3}\right)\right]_{2}$ [17] the methyl groups bound to aluminium were found to be nonequivalent at $22^{\circ} \mathrm{C}$. As the temperature is increased coalescence of the $\mathrm{AlMe}_{2}$ signals occurs. This indicates a lower energy of activation for the metal-nitrogen bond breaking in 1 and therefore a weaker $\mathrm{M}-\mathrm{N}$ bonding at room temperature. 
In comparison to 1 , compound 2 reveals a totally different behavior in solution. In the ${ }^{3} \mathrm{H} N \mathrm{NR}$ spectrum of compound 2, two sets of resonances are observed at room temperature for the $\mathrm{NMe}_{2}-\mathrm{NCH}_{2}$ and $\mathrm{CH}_{2} \mathrm{Ph}$-moieties, respectively. In the free ligand only one signal for the $\mathrm{NMe}_{2}$-group, a multiplet for the $\mathrm{NCH}_{2}$-unit and a sharp signal for the $\mathrm{CH}_{2} \mathrm{Ph}$-moiety are detected. When complex 2 is formed, signal splitting and a change in the coupling pattern of each of these groups take place. Therefore the $\mathrm{NMe}_{2}$ - group is observed as two signals, the $\mathrm{NCH}_{2}$-protons are detected as a part of an $\mathrm{ABC}$ pattern of the $-\mathrm{CHCH}_{2}$-unit linked to the amine, and the $\mathrm{CH}_{2} \mathrm{Ph}$ moiety as an $\mathrm{AB}$ pattern. The higher energy necessary for the dissociation of the $\mathrm{Ga}-\mathrm{N}$ dative bond in the fourcoordinate species 2 prevents break-up of the metal nitrogen bond, therefore fluctional behavior and free rotation around the $\mathrm{Ga}-\mathrm{O}$ bond at room temperature becomes impossible. This provides a satisfactory explanation for the maintenance of the six-membered ring system in solution and the chemical shift nonequivalence of the $\mathrm{NMe}_{2}$ - and $\mathrm{NCH}_{2}$-signals, respectively, observed in the ${ }^{1} \mathrm{H}$ and ${ }^{13} \mathrm{C}$ NMR spectra. The nonequivalence of the methylene protons of the $\mathrm{CH}_{2} \mathrm{Ph}$-group may be attributed to a hindered rotation of the benzyl group, caused by strong interaction with the $\mathrm{GaMe}_{2}$-unit. In the analogous aluminium complex [20] these protons collapse with equivalent chemical shifts, whereas when the bulkiness of the alkyl groups bound to the metal increases for example in the analogous $\mathrm{AlEt}_{2}$ compound [20], diastereotopic behavior of the methylene protons can be observed. Therefore a more restricted rotation around the $\mathrm{CH}_{2} \mathrm{Ph}$ bond and stronger interaction between the benzyl group and the $\mathrm{GaMe}_{2}$-unit compared to the $\mathrm{AlMe}_{2}$-group can be assumed.

\section{Acknowledgment}

Financial support by the Fonds der Chemischen Industrie, the Deutsche Forschungsgemeinschaft, the Bundesministerium für Bildung, Forschung und Technologie (Contract 03D0021A) as well as gifts of valuable chemicals from E. Merck Company, Darmstadt, are gratefully acknowledged.

\section{References}

[1] T. Araki, K. Hayakawa, T. Aoyagi, Y. Nakano, H. Tani, J. Org. Chem. 38 (1973) 1130.

[2] E. C. Ashby, J. T. Laemmle, Chem. Rev. 75 (1975) 521.

[3] G. W. Kabalka, R. F. Daley, J. Am. Chem. Soc. 95 (1973) 4428.

[4] See e.g., J. L. Namy, G. Boireau, D. Abenhaim, Bull. Soc. Chim. Fr. (1971) 3191.

[5] J. Blum, W. Baidissi, A. Rosenfeld, M. Frick, B. Heymer, S. Schutte, H. Schumann, Eight IUPAC Symposium on organometallic chemistry directed towards organic synthesis OMCOS 8, Santa Barbara, California USA, August 6-10, 1995.

[6] (a) G. Boireau, D. Abenhaim, E. Henry-Basch, Tetrahedron 35 (1979) 1457.

(b) E. C. Ashby, L. C. Chao, J. Laemmle, J. Org. Chem. 39, (1974) 3258.

(c) R. Noyori, I. Tomino, M. Yamada, M. Nishizawa, J. Am. Chem. Soc. 106 (1984). 6717.

(d) E. Negishi, S. Baba, A. O. King, J. Chem. Soc. Chem. Comm. (1976) 17.

(e) K. Maruoka, H. Banno, H. Yamamoto, J. Am. Chem. Soc. 112 (1990) 7791.

[7] M. Kretschmar, CAD4 / PC, Universität Tübingen (1994).

[8] N. Walker, D. Stuart, Acta Cryst. A39 (1983) 158.

[9] G. M. Sheldrick, SHELXS 86, Program for Crystal Structure Determination, Universităt Göttingen (1986).

[10] G. M. Sheldrick, SHELXI 93, Program for Crystal Structure Determination, Universităt Göttingen (1993).

[11] D. T. Cromer, J. B. Mann, Acta Cryst. A24 (1968) 321.

[12] D. T. Cromer, D. Liberman, J. Chem. Phys. 53 (1970) 1891.

[13] R. F. Stewart, E. R. Davidson, W. T. Simpson, J. Chem. Phys. 42 (1965) 3175.

[14] L. Zsolnai, H. Pritzkow, ZORTEP, Ortep Program for PC, Universität Heidelberg (1994).

[15] (a) R. T. Baker, S. J. Rettig, A. Storr, J. Trotter, Can. J. Chem. 54 (1976) 343.

(b) A. Arduini, A. Storr, J. Chem. Soc., Dalton Trans. (1974) 503.

[16] (a) R. Benn, A. Rufinska, H. Lehmkuhl, E. Janssen, C. Krüger, Angew. Chem. 95 (1983) 808; Angew. Chem., Int. Ed. Engl. 22 (1983) 779.

(b) M. R. P. van Vliet, P. Buysingh, G. van Koten, K. Vrieze, B. Kojic-Prodic, A. L. Spek, Organometallics 4 (1985) 1701.

(c) S. T. Dzugan, V. L. Goedken, Inorg. Chim. Acta 154 (1988) 169. 
(d) D. G. Hendershot, M. Barber, R. Kumar, J. P. Oliver, Organometallics 10 (1991) 3302.

(e) F. H. van der Steen, G. P. M. van Mier, A. L. Spek, J. Kroon, G. van Koten, J. Am. Chem. Soc. 113 (1991) 5742.

(f) S. J. Rettig, A. Storr, J. Trotter, K. Uhrich, Can. J. Chem. 62 (1984) 2783.

(g) G. A. Banta, S. J. Rettig, A. Storr, J. Trotter, Can. J. Chem. 63 (1985) 2545.

(h) E. C. Onyiriuka, S. J. Rettig, A. Storr, J. Trotter, Can. J. Chem. 65 (1987) 782.

(i) S. J. Rettig, A. Storr, J. Trotter, Can. J. Chem. 53 (1975) 58.

(j) W.-T. Tao, Y. Han, Y.-Z. Huang, X.-L. Jin, J. Sun, J. Chem. Soc., Dalton Trans. (1993) 807.

(k) H. Schumann, M. Frick, B. Heymer, F. Girgsdies, J. Organomet. Chem., in press.

[17] M. L. Sierra, V. S. J. de Mel, J. P. Oliver, Organometallics 8 (1989) 2486.

[18] (a) K. S. Chong, S. J. Rettig, A. Storr, J. Trotter, Can. J. Chem. 57 (1979) 586.

(b) G. D. Gracey, S. J. Rettig, A. Storr, J. Trotter, Can. J. Chem. 65 (1987) 2469.

(c) S. J. Rettig, A. Storr, J. Trotter, Can. J. Chem. 65 (1987) 1349.

[19] V. I. Bregadze, N. G. Furmanova, L. M. Golubinskaya, O. Y. Kompan, Yu. T. Struchkov, V. A. Bren, Zh. V. Bren, A. E. Lyubarskaya, V. I. Minkin, L. M. Sitkina, J. Organomet. Chem. 192 (1980) 1.

[20] R. Kumar, M. L. Sierra, J. P. Oliver, Organometallics 13 (1994) 4285.

[21] S. J. Rettig, A. Storr, J. Trotter, Can. J. Chem. 54 (1976) 1278.

[22] (a) K. S. Chong, S. J. Rettig, A. Storr, J. Trotter, Can. J. Chem. 55 (1977) 2540.

(b) S. J. Rettig, A. Storr, and J. Trotter, Can. J. Chem. 53 (1975) 753.

Received: January 8, 1996 - Accepted: February 6, 1996 - Received in revised camera-ready format: February 15, 1996 